\title{
Comfortably Invisible: The Life of Chinese Migrants Around 'The Four Tigers Market' in Budapest
}

\author{
Boglárka Szalai and Krisztina La-Torre
}

\begin{abstract}
Although in Hungary - as in most Eastern European countries - the foreign population is rather small, i.e., less than three per cent of the total population (KSH 2011), and consists primarily of ethnic Hungarians from neighbouring countries with the same cultural background and mother tongue, there are a few urban areas where the presence of immigrants is 'visible' and significantly influences the local communities' everyday life. According to the latest census (KSH 2011), immigrants coming from Asia - including around 7000 Chinese and 2000 Vietnamese citizens - constitute around 16,000 people within Hungary.

In this chapter we will provide an overview of the inter-group relations between Hungarians and non-EU immigrants - in particular those from China and Vietnam who settled in two districts of Budapest. Although there are many districts within the capital that host smaller Asian communities, we chose Józsefváros (8th district) and Kőbánya (10th district) for our investigation as Chinese and Vietnamese migrants have the highest territorial concentration here (Köszeghy 2010). In addition, these two districts were the first ones where non-EU immigrants settled down historically, hence various forms of inter-group relations can be observed here right up to the present day. While being both relatively old settlement areas, these two districts represent two distinct types of urban environment: Kóbánya is a large, peripheral former industrial area, while Józsefváros is a small central district with a more mixed population.
\end{abstract}

Among the economic and social factors that have led to the over-representation of these immigrant groups in these two particular districts, a key role is played by the large Chinese Market situated at the boundary between Józsefváros and Kőbánya. While the relations between host society and immigrants are at the core of our investigation we also consider other aspects of inter-group dynamics.

B. Szalai $(\bowtie) \cdot$ K. La-Torre

Independent researcher, Budapest, Hungary

e-mail: szalaiboglarka@gmail.com; kri.la.torre@gmail.com 
The presence of a sizeable Roma population in the selected districts - especially in the 8th district - must be pointed out as a specific additional factor in the fragmentation of the host society along ethnic lines given the spreading of discriminatory attitudes towards this national minority in Hungarian society, especially since the extreme right-wing party, Jobbik - and its ideas - have gained momentum in the last decade. ${ }^{1}$

After introducing Józsefváros and Kőbánya, the interaction sites studied in our research, with a brief discussion of their historical heritage, current economic and social circumstances, and the situation of their Roma inhabitants, we will give an overview of the main characteristics of Chinese migration to Hungary based on relevant literature, statistics and interviews conducted in the summer of 2011. Before analyzing the main features of inter-group relations in the two neighbourhoods, we will focus on the institutions' role in the representation and discourse formation of each group (Roma, non-Roma and the different migrant groups). Finally, taking the empirical evidence from the fieldwork in the selected interaction sites as a starting point, we will discuss the nature of relationships among immigrants and Hungarians.

\section{Inter-group Relations in Statistics and Inhabitants' Perceptions $^{2}$}

In spite of their difference in location and size, the two neighbourhoods show some important similarities in key economic and social parameters, all of which help to explain both the relatively high concentration of immigrants and their degree of

\footnotetext{
${ }^{1}$ According to a recent study (Simonovits-Szalai 2012) almost half of Hungarians would not accept a Roma person either as a family member, a neighbour, or a colleague, and almost $60 \%$ would not allow their child to play with a Roma child.

${ }^{2}$ Methodological footnote: The chapter is based on relevant literature, data provided by the Hungarian Central Statistical Office (KSH), Immigration Office of Hungary (BAH) and the results of the interviews conducted within the framework of the 'Concordia Discors' project. In total 37 semi-structured interviews ( 20 with natives and 17 with immigrants) were conducted during the summer of 2011. The language of the interviews was mainly Hungarian except for one in Orczy Square with a Vietnamese resident, conducted in English, another one, conducted in French with an Angolan immigrant, and a third one conducted in Chinese with the assistance of an interpreter. Within Józsefváros 9 interviews were held in 'Four Tigers Market', 15 in Népszínház Street, and 6 in Orczy Square. In Kőbánya, 3 in Taraliget Residential Park, 4 in Hungária Avenue. Mental maps were also created by the interviewees in order to analyze the subjective evaluation of the living environment and the urban space and to explore the assumption that there is a hidden association between space and migrants. When conducting the interviews we faced two main difficulties; the first one was the lack of presence and availability of Hungarian-speaking Chinese migrants. The second challenge came from a terminological uncertainty that is a telling example of the neglect of the topic of immigration in Hungary, namely that the Hungarian vocabulary for immigration issues is very vague and controversial. While conducting the interviews we had difficulties in finding a shared and effective Hungarian term to indicate immigrants as the term 'immigrant' ('bevándorló') has pejorative connotations, and when
} 
segregation from natives. In particular, a key feature shared by both neighbourhoods is a sizeable Roma presence, which strongly influences local integration dynamics and has thus pushed us to extend our research focus to the triangular relations between native Roma, native non-Roma, and non-EU immigrants.

For more than a century, Józsefváros has been undergoing a process of slow but steady decline that is also reflected in the changing composition of its population. During the last decades of the nineteenth century, when large-scale construction projects thrived throughout the capital, the growing industry (railway, factories) had lured workers to the district while those better off could afford to build the prestigious houses of the Palotanegyed (Palace Quartier - the inner circle of Józsefváros). The local society, mainly composed of petite bourgeoisie, craftsmen and workers, then had to face the downfall which started shortly before the First World War. During the 1920-1930s the district already had major problems with prostitution, poverty and housing. Roma migration from the countryside also boomed in this decade (György 2012). The damage after World War II was severe and the official discourse regarding the district was soon narrowed down to two main narratives: a developmental and a criminal one (which was not without antecedents; see Dupcsik 2009). The latter - opposing the socialist, 'colour blind' propaganda - suggested a causal relation between the number of Roma inhabitants and the severity of crimes and social problems (György 2012). The uneven social housing programs in the socialist era (see Szelényi-Konrád 1978) led to more severe marginalization in the district, resulting in a vicious circle. The only exceptions - present both in official documents and in scholarly literature (Solt 1975) - were the 'musician gypsies' who had a sort of elite status in the district and among the Roma community. When their numbers gradually dropped in the area, this symbolized both a cultural change and the growing ghettoization of Józsefváros.

Kőbánya's case is different in many respects and less symbolic at a discourse level. During the nineteenth century, vineyards and mines gradually gave way to industries (iron foundries, breweries and pharmaceutical plants) (Kasza 2005). Up until the end of the nineteenth century, another important aspect of the local economy was the swine and livestock market. Historically, this part of the city had a

we used it people often thought we were referring to the Roma. 'Foreigner' ('külföldi' in Hungarian) was not the appropriate term either, since some immigrants have obtained Hungarian citizenship, and in everyday language the term 'foreigner' also includes tourists. Therefore, we often said 'foreigner who lives in Hungary' to describe immigrants, but this did not feel right either because it is too wordy. During our interviews this terminological issue caused only minor inconvenience but the lack of a widely understood and used terminology for this topic shows the neglect and ignorance of both public opinion and everyday discourse. Some of the interviewees refused to tell us their age and thus in those cases we have provided a rough estimate based on our perception and on the information received during the interviews. Four of our interviews were carried out as 'walking interviews', to gain information about the inter-group relations among specific individuals, focusing on the everyday experience of their sites in order to single out residents' representations of differences, on the one hand, and to investigate everyday practices and daily encounters on the other. The route of the interview was discussed in advance with the interviewee, and during the walk the interviewee was asked to tell stories about the sites, the buildings and intergroup relations. 


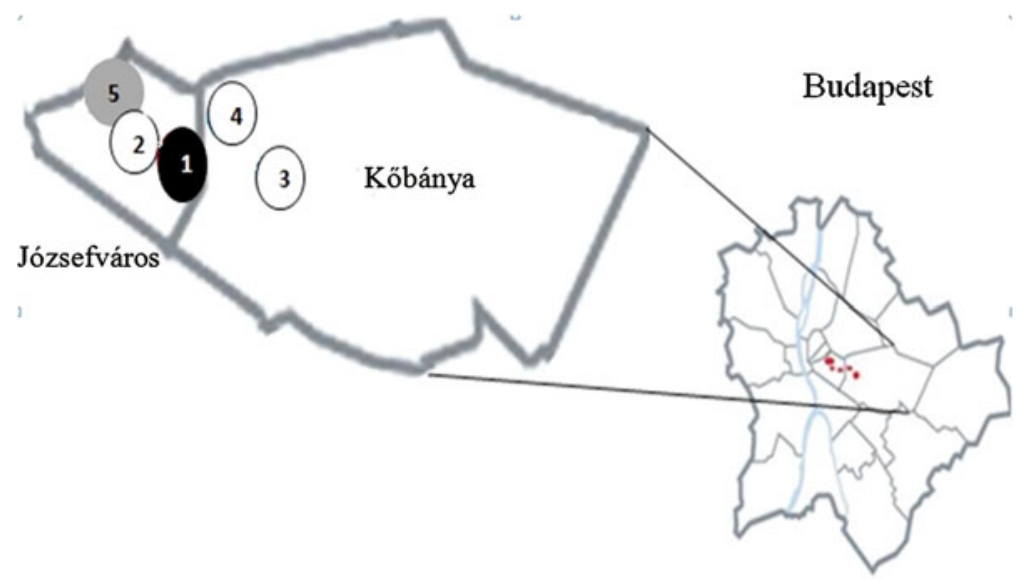

Fig. 1 The location of the five interaction sites in this study: (1) Four Tigers Market; (2) Orczy Square; (3) Taraliget Residential Park; (4) Hungária Avenue; (5) Népszínház Street. As we will see in greater details below, (1) and (5) are essentially commercial sites, while the other ones have a predominantly residential nature

strong agricultural and working-class image and was populated by vendors and labourers. Housing problems were already quite severe in the 1920-1930s due to the rapid population growth of the previous decades - mainly from labour migration driven by industrial development (Szalai 1970). A solution came in the form of blocks of flats erected in the socialist era, which helped to increase the general comfort level of the habitants while irreversibly changing the landscape and atmosphere of the district (Kasza 2005). The interaction sites we investigate in this chapter are all located in the inner part of Kőbánya, and they have important features in common with the 8th district, such as the presence of Chinese communities.

While Józsefváros and Kőbánya host almost the same number of inhabitants today - around 80,000 people each - Józsefváros with a surface area of $6.9 \mathrm{~km}^{2}$ is the fifth smallest centrally located district, while Kőbánya with a surface area of $32.5 \mathrm{~km}^{2}$ is one of the largest peripheral districts of Budapest. As a result, Józsefváros is one of the most congested districts of Budapest, with more than 11,000 inhabitants per square km (Fig. 1).

Both Józsefváros and Kőbánya are strongly affected by poverty, unemployment, homelessness and short life expectancy compared to other districts of Budapest and Hungary as a whole. Based on Józan's (2006) calculations regarding average income and life expectancy Józsefváros and Kőbánya are lagging behind the rest of the capital; a child born in one of these districts is very likely to grow up in one of the poorest families of Budapest and to die 10 years earlier than those born in the most prestigious district of the city (2nd district).

Unemployment rates for both Kőbánya and especially Józsefváros are significantly higher than that of Budapest (14.9\% in Józsefváros and $10.8 \%$ in Kőbánya, $9 \%$ in Budapest as a whole). More than half of the jobseekers of Józsefváros are 
long-term ones, ${ }^{3}$ which is $10 \%$ higher than that of Köbánya and the city as a whole. Furthermore, almost $80 \%$ of all job seekers from Józsefváros and Kőbánya are unskilled workers, a figure which is almost $20 \%$ higher than at city level.

The distribution of jobseekers by education level also reveals the working and lower class background of both districts; the proportion of jobseekers with lower than secondary education is $10 \%$ higher in Józsefváros than in Kőbánya, which in turn is $5 \%$ higher than in Budapest. One piece of striking evidence of the disadvantaged situation of these districts is the critically low number of tax-payers and payed taxes; almost half of the working age population in Józsefváros does not pay any kind of income-related tax while this percentage is $10 \%$ lower in Kóbánya and $20 \%$ lower in Budapest. The disadvantaged economic situation of both Józsefváros and Kóbánya is also reflected in the depressed property prices compared to the rest of the city, ${ }^{4}$ which is a decisive factor for the poorer strata to choose these districts as their place of residence and a burden for those who would like to move from these neighbourhoods. According to the Integrated Social Rehabilitation Study of the municipality of Józsefváros (2012) criminality, including crime committed by young people (under 18), is a major problem of the district which is highly correlated to the fact that almost four out of ten children are living in a disadvantaged situation. Based on a survey conducted by the municipality between 2003 and 2005, $15 \%$ of all households have been victims of burglary. According to the statistics of the Ministry of Home Affairs (ORFK 2008) on the number of registered perpetrators per 100,000 inhabitants, Józsefváros (with 1856 people) has the second highest ranking and Kóbánya (with 1137 people) comes in fifth out of the 23 districts of Budapest (2008).

The image of the two districts studied, especially that of Józsefváros, is rather degraded, both in the media and in the public discourse. Although $10 \%$ of registered criminal offenders are from Józsefváros (KSH 2011), and not more than $10 \%$ of all registered crimes in Budapest are perpetrated here, the local and national media put a disproportionate emphasis on crime-related news, thereby constantly reinforcing the negative image of the district. As an inhabitant explained:

I have a straight stroke when I hear on the TV about the "infamous" Józsefváros. Please show me a district, which is as diverse as this one. (Józsefváros, municipal representative, 39 years old)

Józsefváros has recently been going through the initial stages of a gentrification process, and some parts - such as the Corvin area - are now a residential target for young and wealthy settlers while the poorest inhabitants are sidelined and pushed towards the outskirts (Benedek 2007). In spite of this ongoing process, the dominant view of the neighbourhood at city level is still far from positive. Many locals share a desperate and pessimistic common attitude towards the district and its future prospects:

\footnotetext{
${ }^{3} \mathrm{~A}$ long-term jobseeker is defined here as an unemployed person who could not find a job for over 180 days.

${ }^{4}$ According to the data of OTP Residential Property Value Map the average flat price in Józsefváros is more than $25 \%$ lower, $34 \%$ lower in Kőbánya compared to the prices of the capital (in Budapest in 2011 is $~ 980 \mathrm{EUR} / \mathrm{m}^{2} 300.000 \mathrm{HUF} / \mathrm{m}^{2}$ ), in Józsefváros the average prices are lower than 720 EUR (2221.000 HUF)/m² and in Kőbánya 650 EUR (200.649 HUF)/m² $)$.
} 
Every evening, my daughter asks me when we are moving, but I say I do not know, perhaps when this house will explode" (44 year-old Hungarian woman, shop assistant). However the unique atmosphere has its power: 'Shopkeepers often sit in front of their shops, it cannot be compared with other parts of the district. It is very unique, that strangers here say Hey brother, what's up, like in the villages and I really like it. (Józsefváros, municipal representative, 39 years old)

The most frequently mentioned problems during our interviews were homelessness and the Roma presence. Both groups are systematically used by our interviewees as living evidence of the decay of their neighbourhood. They are mostly mentioned within a context consisting of nostalgia for the past system and criminalizing poverty:

I do not like Józsefváros. Well, how is it possible to like a Roma neighbourhood? It was not different many years ago, but there were not so many unemployed people because those who did not work were arrested. Now the Roma have rights but they do not have any duties. (Józsefváros, owner of a bakery, 71 years old)

Within deprived and marginalized areas, the cohabitation of Roma and nonRoma neighbours is strongly marked by conflicts. Public safety is one of the main frameworks through which this conflict is displayed. Asian immigrants seemed to be especially concerned about their own safety and threats that, according to them, may come from Roma - a few have already been a victim of petty crime - and they only go to places they trust and consider safe.

I do not like walking on the streets in the evening alone in the darkness because the dark people [she points at a Roma man through the café window] sometimes make a pass at me and they are watching me suspicious. I do not like this. We always go home together, I like moving in groups for that reason it is good that I live together with my colleague. (Józsefváros, waitress, around 30 years old)

It is mainly the Roma who are blamed for the deterioration and unfavourable image of the area, as clearly expressed by one of our interviewees:

There are protective iron bars everywhere on buildings, but when I was a young assistant, these barred doors did not even exist, though there was a crisis for a long time, and there were already gypsies there. [...] Nowadays they toss the trash here, in front of the shop, they spit, they lie drunk in front of the shop; this is in their blood, this society is abysmal. (Józsefváros, jeweller, around 60 years old) ${ }^{5}$

Regarding the Roma's point of view, we must say they feel that they are discriminated against, especially in the labour market, as a Roma woman explains:

If you wanted to hear all of my stories about being a victim of discrimination, you had to sit here until midnight. If you are Roma, you have to work ten times as much to be accepted by employers and colleagues. For example, in the restaurant where I used to work, I was the most hardworking among the colleagues, and still sometimes I heard some murmurs about my blood. (Józsefváros, shop assistant, 44 years old)

\footnotetext{
${ }^{5}$ The empirical results of our qualitative fieldwork are consistent with the results of a public opinion survey conducted by TÁRKI in 2011, which reported on the highly discriminatory attitudes of Hungarians. According to that survey, more than 6 out of 10 Hungarians share the opinion that criminal traits are biologically determined - as one of our interviewees puts it: "it's in one's blood".
} 
It seems that they are less accepted than immigrants most of the time, serving as the main scapegoats for problems, and the main target of prejudice. According to one of our Roma interviewees the prejudice of Hungarians materializes in everyday situations, including the labour market, where immigrants are preferred over Roma. This perceived preference by employers contributes in turn to generating a sort of 'reflected' anti-immigrant prejudice among Roma which feeds itself with economic arguments.

Honestly, I do not really like the way foreigners anchor themselves in the district as residents. The time will come when they will look at the people living here - the rooted ones as if they were nothing. That's why ignoring the Roma workforce is a huge mistake. The Roma should be counted as a really important inside reserve of workforce. Because if you do not invest now in developing the human capital of the Roma people, you will regret it seriously. Our culture, our religion, the language is common. And you could make a decision to ignore Roma people, but then the Chinese, Arabs, and Muslims will have no intention to know about Hungarian culture. (Józsefváros, municipal representative, 39 years old)

\section{Chinese Migration to Hungary ${ }^{6}$}

Before we examine the present situation of inter-group relations in the Four Tigers Market area, it is first necessary to look back to the transition period in which Hungary emerged as one of the main destinations for Chinese migration to Eastern Europe. Historical memories are still decisive factors in shaping the Hungarians' perceptions of the Chinese who were among the first international migrants to appear in the early 1990s, at a time of severe economic difficulties for natives.

Chinese migration to Hungary was driven by multiple push and pull factors, including a short period of liberal immigration policy in the early 1990s. Hungary's newly adopted market economy and transitional redistribution of goods made the country an attractive destination for the entrepreneurially-minded. During this time in China, a massive economic change was just about to gain momentum as a result of the 'Reform and Openness', (Gaige Kaifang, 改革开放) which began under Deng Xiaoping and had started to take effect. Thanks to the short visa-free period between 1990 and 1991, the number of Chinese immigrants rose to about 30-40,000 persons. The Chinese began to appear in 'Comecon' open-air markets - as it happened at the 'Four Tigers Market' - soon forcing out Hungarian vendors with their extremely low prices and larger variety of goods. ${ }^{7}$ According to Nyíri (2001) many of the Chinese present here today are early settlers, who originally came from the Fujian region (Fig. 2).

\footnotetext{
${ }^{6}$ We would like to thank Mounia Utzeri for her contributions to this chapter.

${ }^{7}$ Comecon: Council for Mutual Economic Assistance was an economic organization between 1949 and 1991 set up by the Soviet Union that aimed to unite the countries of the Eastern block. The open air markets of the era had an important function in the shortage economy as rare and imported goods could be purchased under almost free market conditions regarding the price setting. For more details about the transformation process of the Hungarian markets see Sik (2010).
} 


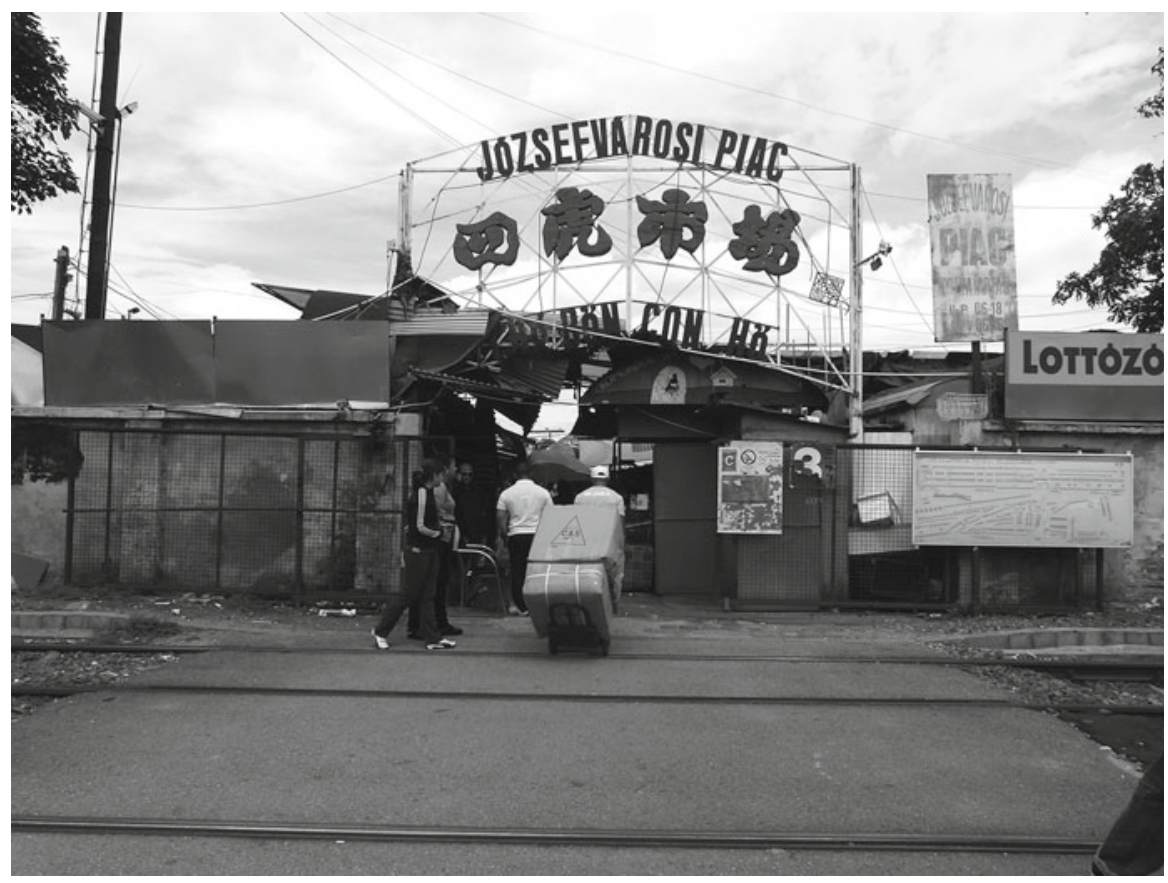

Fig. 2 Entrance of the 'Four Tigers Chinese Market' (Photo by J. Sebő)

Our findings confirm Nyíri's (2010) arguments: Chinese migration to Hungary has been mainly driven by economic motives. All of our Asian interviewees mentioned business as the main reason for their move. As explained by Tilly (2007 [1993]) and Nyíri (2010) their migration was supported by extremely strong transnational ethnic bonds; the final decision to migrate to a given country is generally initiated and supported by relatives or acquaintances already settled in the target country. On arrival many of our interviewees knew nothing about Hungary or Budapest in general or about Kőbánya or Józsefváros in particular, except for the existence of the Four Tigers Market: this is hyper-localized transnational migration from a specific Chinese region to a specific area in Budapest. A common practice among first-wave migrants was to leave their children in China and send for them a few years later when the circumstances were appropriate.

Before I came here, I did not know anything about Hungary, but my parents said 'come', and now we are here. At that time I did not think whether I liked it or not, my parents just said 'come', and I came. (Józsefváros, entrepreneur, 29 years old)

Intentions vary, but they are mainly determined by the working conditions and profitability of business especially for those with a stronger mainland Chinese background.

I have no idea on what will happen in the future, but I am not afraid about going to work anywhere in the world, I will always find a job. For me it's no question. (Józsefváros, age approx. between 40 and 50 years old). 
Whereas the early Chinese migration is characterized by high transnational mobility due to a widespread and well-established European network, the immigrants arriving in the past few years tend to share fewer provincial ties with China and identify themselves more with the whole country. These newcomers - mostly from Shanghai or the north-eastern provinces - differ from their predecessors in seeing themselves not as local minorities, but as a 'global majority' (Nyíri 2001) with a strong national attachment to their homeland. The greater ethnic confidence and national pride may be a factor in intra-group tensions between the new generation of migrants and old settlers.

The first generation of Chinese migrants say that they do not feel the need to learn Hungarian because they do not associate with Hungarians, either in their private life or in business. This lack of assimilation is demonstrated by the limited language acquisition of vendors at the Four Tigers Market. Here a so-called 'marketlanguage', a 'lingua franca' has developed. It is mostly used by Asian migrants to communicate with Hungarian customers, employees and other traders with a limited vocabulary, and only contains words used in business situations (i.e., numbers, sizes and quantities). For this reason Hungarians often perceive Chinese as being self-segregating:

Immigrants do not seek Hungarians' company. They do their business with each other. (Józsefváros, owner of a shop, 33 years old)

The negative effect is also problematic for those younger Chinese who try to seek Hungarian friends:

Good, the neighbour is good, everything good, but no friend, no girl because it is difficult for me, don't speak well Hungarian. (Józsefváros, owner of a shop, age approx. between 40 and 50 years old)

The lack of social interaction with Hungarians strongly influences the perception of the majority. A telling example of such a one-dimensional if not outright distorted perception is the opinion, held by a significant number of Hungarians, that the Chinese will 'invade' the country:

The time will come when they will look at the host society as if they were nothing. They do not want to know about Hungarian culture. If they come into the country, they will develop their own institutional systems, and they will push us out of this country. This time will come, believe me. (Józsefváros, municipal representative, 39 years old)

Although the majority of Chinese immigrants - especially those from older generations - do not speak Hungarian, those who were born in Budapest or are from the second generation of migrants, speak the language and want to be considered Hungarian to reinforce relations with their native Hungarian peers.

Kids already speak both Hungarian and Chinese very well. The two older ones have already been to China, they like it a lot, but they like Hungary more. They live in Hungary, they think they are not Chinese, but Hungarian. I don't mind, even if they wouldn't know the culture so much, I don't care, I just want them not to be sad, let them be happy kids. (Józsefváros, entrepreneur, 29 years old)

Some can see the changes this new life made on their personality: 
I have changed a lot here, but not only my outlook has changed, I am also much more open. I think that Hungarian people like me because I am very different from other Chinese because I love talking and I would like to make Hungarian friends so much. (Józsefváros, waitress, around 30 years old)

Business thus plays a central role in constructing and structuring the community: economic, social and, to a certain extent, cultural relations are built around an entrepreneurial basis. Almost all of these businesses are run and supported by a network of ethnic solidarity in financing, supplying, and personnel recruiting. A fundamental distinction can be drawn between intra-community activities (sale of goods and services of an ethnic nature, often with a function of identity consolidation and reproduction, such as in the food and leisure sectors) and extra-community activities targeted at native Hungarians with no migratory background (essentially catering, consumer goods, and supplying local companies). Through an internal supply and demand system, the Chinese economic web generates an elaborate Chinese ethnic labour market, which is a manifestation of a process of striving to achieve economic and social autonomy. The most striking consequence of this is the lack of contact with the host society, something which was frequently criticized by the Hungarian interviewees. It seems, however, that the classic ethnic economy is turning into an enclave economy, thriving in a diversification of its activities (i.e., finance, insurance and professional services) increasingly integrated in the mainstream economy.

\section{Does Place Really Matter? Inter-group Relations in Commercial and Residential Areas}

Immigrants settling down in our sites of interaction showed two distinct strategies of coexistence. Some follow a peaceful, but isolationist approach whereby encounters with the host society are reduced to a minimum; others opt for an active involvement in shaping their environment and engagement in encounters. We argue that these strategies depend on the urban function of the place where the encounters take place. The five sites of interaction we examined are situated close to each other, yet they have different urban functions (see above, Fig. 1). While three of them - Orczy Square, Taraliget Residential Park and Hungária Avenue 5-7 - serve as residential areas for those working on the Chinese market ('residential sites'), two of them Népszínház Street and the 'Four Tigers Market' itself - mainly perform productive functions and are where a significant proportion of the foreign immigrants earn their living ('commercial sites').

\subsection{The Two Commercial Interaction Sites}

The 'Four Tigers Market' - the most important of our sites as a key area for early economic insertion of Chinese migration to Budapest - has been operating since the early 1990s and has been lent by the owner of the area (Hungarian State 
Railways - MÁV) to the entrepreneurs who have actually operated it since 1997. Due to the absence of any residential buildings within its premises, this is an exclusively commercial area. This feature strongly influences the integration process of immigrants working there by shaping how they are perceived by the Hungarians. Furthermore, the market has given rise to several urban legends and has become the symbol of the Hungarian black market because a wide range of illegal products can be purchased there. Police raids and tax-controls on the market are very common, and for more than a decade Hungarian media reported every year on the closure and relocation of the market, which eventually happened in the summer of 2014. ${ }^{8}$ Its total closure was explained by the right-wing mayor of Józsefváros to be for security reasons. He stated in the Hungarian media that "the market is a centre for criminal activity". ${ }^{9}$

The particularly high level of interethnic tension in this area can be attributed to several factors. At one level the market is regarded by most natives as the main reason why Józsefváros is at the top of the statistics for criminal activity, while tax evasion and black market activity are often blamed for jeopardizing the economic interests of the local majority population. As evidence of the negative effect of the market on the criminal situation, every interviewee could recall crime stories on the market.

In the Chinese market, there are criminal gangs specialized in stealing and pick-pocketing, or they sell VAT invoices if you want to cheat on taxes. In that place everybody steals from everybody, but the Chinese people do not steal the usual way. They steal in the way that they do not pay taxes and that their products are counterfeit. For this reason immigrants who work on the Market can just be harmful to the district because they do not pay taxes. (Józsefváros, bakery owner, 71 years old)

In the meantime, the market as a working place also gives rise to other conflicts mainly originating from diverging attitudes towards work and private property. According to both experts and Asian interviewees, Chinese work standards are very high. Taking too many breaks or being less punctual and dedicated is poorly tolerated: the image of a strict Chinese boss is shared by many interviewees. First encounters were often based on trying to match Chinese employers' demand for work and the vast low-skilled Roma labour supply. According to most interviewees, many of these employment relations were short-lived due to allegedly irreconcilable differences in work ethics.

I personally never have had any conflict with immigrants but in the past one and a half years I have seen at least five massive brawls when Asians beat the Roma. The cause is always the same. Either the Roma steal from them, or they cheat by doing the work slowly. (Józsefváros, shop assistant, 42 years old)

Issues regarding stealing often resulted in physical conflict, and if the vendors could find the thief they would not refrain from vigilantism.

\footnotetext{
${ }^{8}$ According to Gergely Salát (2013) the closure of the market will not significantly affect the everyday life of the Chinese community who will be able to move to a nearby area.

${ }^{9}$ Source of the citation: http://index.hu/belfold/2014/06/16/jozsefvarosi_piac/.
} 


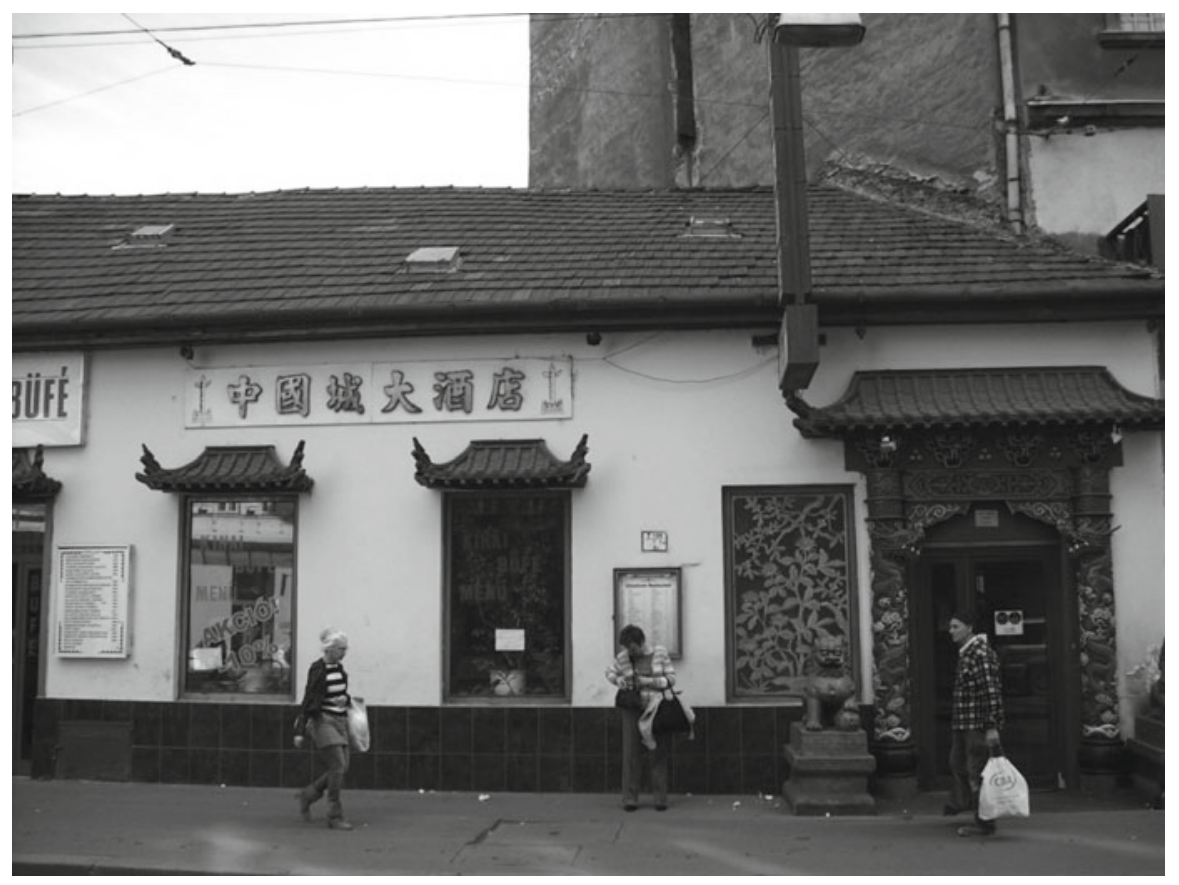

Fig. 3 Chinese restaurant in Népszínház Street (Photo by B. Szalai)

At the same time, one positive feature cannot be disregarded, not even by the most prejudiced Hungarians: the market plays a crucial social function for Hungarians since in Józsefváros there is a segment of residents that would not be able to afford new items if the market did not exist (Fig. 3).

Népszínház Street, situated in a central part of Józsefváros, is a mixed site combining commercial and residential features. Although it is also a residential area, its market serves as one of the most important wholesale centres for the Chinese and Vietnamese retailers working in Népszínház Street, while some retailers prefer to live in the area due to its proximity to their workplace such as many petty native retailers, who own small shops on this street. Home to a flea market since the early twentieth century, the street has always been a site for small family-owned shops. In the aftermath of the political and economic transition of 1989-1990, shopkeepers from East-Asia, the Middle-East and Africa converted this area into one of the few multicultural sites of Budapest. This 'multiculturalism' however is tense and prejudiced rather than mutually enriching and community-forming. Here local Hungarians often explain the tensions as a result of the dumping by Chinese and Vietnamese businesses, which has basically forced them out of the market. They suspect that these low prices are only possible because of semi-legal or outright illegal commercial practices, such as tax evasion and privileged commercial conditions for mem- 
bers of the community. ${ }^{10}$ These rumours obviously tend to reinforce the discontent of local businessmen towards their Asian peers.

I have my own opinion about the Chinese and the Vietnamese. I buy at higher prices from the wholesale trader than he sells it for, which is funny. It is not acceptable that in the TESCO, a Milka chocolate tablet is 250 forints, and he can sell it for 159 forints here. We reported this unfair competition to the Tax Office, saying that this is likely to be a tax evasion, but they do not care about this. (Józsefváros, shopkeeper, 33 years old)

This street also serves as a working place for several shopkeepers, who are mainly from North Africa and are often indistinctly labelled as "Arabs"11 by the Hungarians. This enables us to compare Chinese-Hungarian and Arab-Hungarian interactions. Some dubious competition behaviour by North African shopkeepers was reported but according to the interviewees, the typically "Arab practice" of reducing potential competition by buying shops just in order to keep them shut to prevent competition is more tolerable than the Asians' price dumping practices. Hungarian shopkeepers feel that they can compete with this practice as it is a fair form of competition (at least it is not illegal, as they don't cheat on taxes or set too low prices). They also have the idea that the closed shops mean less competition for them as well.

Besides their commercial practices, interviewees from the host society and other immigrant groups also mentioned better knowledge of the Hungarian language and a higher propensity to mixed marriages and partnerships as reasons why "Arabs" are more integrated than other groups.

\subsection{Residential Interaction Sites}

The importance of urban space in shaping inter-group relations can be further illustrated by the case of the three residential sites (Hungária Avenue 5-7, Taraliget Residential Park, and Orczy Square), all situated in close proximity to the Market (Fig. 4).

The first Chinese migrants in the 1990s moved to low prestige real estates, such as Hungária Avenue 5-7, inhabited mostly by working class citizens. As a layer of Chinese immigrants succeeded in saving enough money to change their place of living, they moved to newly built and more prestigious buildings, such as Taraliget

\footnotetext{
${ }^{10}$ For example interest-free credits, or arrangements whereby the shopkeeper can bring the products back to the wholesale trader if they are not able to sell them, and the wholesale trader returns the shopkeeper's money.

${ }^{11}$ From now on we will adopt the oversimplified terminology used by native inhabitants who call "Arabs" all those coming from a wide region stretching from the Middle East (Syria) to North Africa, mainly Egypt and Tunisia, without making any further distinction based on the country of origin.
} 


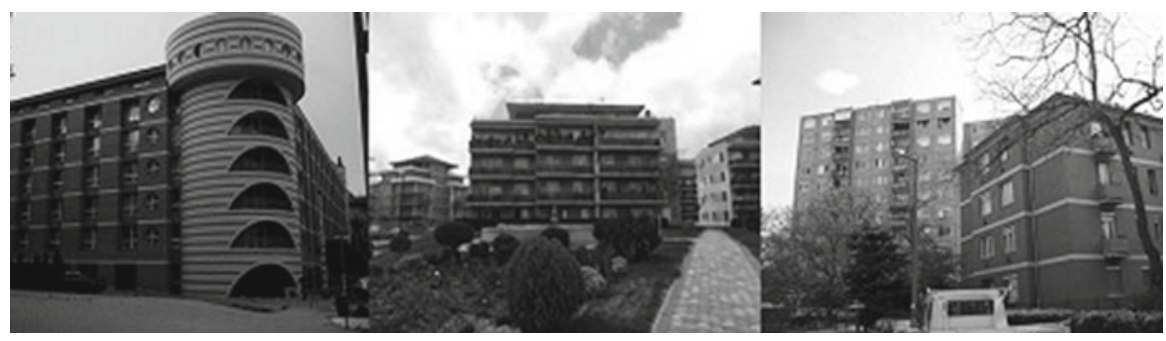

Fig. 4 The three residential sites: Orczy Building (marked no. 2 on Fig. 1), Taraliget Residential Park (marked no. 3 on Fig. 1) and Hungária Avenue 5-7 (marked no. 4 on Fig. 1) (Photo by B. Szalai)

Residential Park and the Orczy Building. Though surrounded by unused industrial buildings and the ruins of Communist era construction, these two buildings are considered as quite trendy and 'fancy'. The Orczy Building - situated less than one kilometre from the market - was built in the early 2000s. Taraliget Residential Park, the newest of the researched sites of interaction, is a high prestige residential park built by a Chinese company, surrounded by a fence, and also situated less than one kilometre from the market.

The conflicts between majority residents and Asian migrants occurring in these residential areas, especially in Taraliget and the Orczy Building, often refer to behaviours that natives are not used to, such as "smelly Chinese food". These minor problems arising from coexistence cannot, however, be compared to the conflicts observed at the Market.

To better understand the frame of the coexistence in residential areas, we have to focus again and more closely on Chinese attitudes towards work. According to both Hungarian and Chinese interviewees, business is the most important area of Chinese migrants' life. As the common stereotype goes, they work hard for their money, and often subordinate private life to business. According to the residents' representative of Taraliget Residential Park, who is in charge of all the operational issues of the Residential Park such as collecting overhead and common costs, taking care of small repairs, mediating between the residents when arguments arise, etc., Asian residents live in small flats, even if they are wealthy and have an expensive car, because their flats only perform the function of accommodation for the night. According to our key informants that is the reason why they do not buy luxury houses in more attractive parts of Budapest. When choosing a place of residence, the most important criterion is the short distance to the workplace.

I think their attitude to all kind of economic activities is very different from what we are used to. I'm sure that they work much more than us, it means 12 hours a day, but their demands are lower than ours. For example, it's a common thing among them that two families live together in a small $60 \mathrm{~m}^{2}$ flat which we could not imagine. It's a really different frame of mind than ours. (Budapest, ${ }^{12}$ leader of NGO called EDIKTUM, age unknown)

${ }^{12}$ The NGO does not operate in any of our sites but has clients mainly from our target areas. 
Among the residential sites, we found the most intense native-immigrant relationships in Taraliget Residential Park and Hungária Avenue 5-7. Since Chinese adults usually work at least $10 \mathrm{~h}$ a day, they have no time to look after their children, so they hire Hungarian 'grannies' aged about 50-60 to baby-sit their children. These ladies, who all live nearby, but not in the same buildings, often take care of their own grandchildren and the Chinese children at the same time. This kind of relationship is considered highly beneficial for both sides. Hungarian 'grannies' can supplement their incomes, and babysitting the children gives them a feeling of usefulness, thus they begin to live more actively. From the Asian parents' point of view, these ladies can help their children to improve their knowledge of the Hungarian language and culture. In these cases, children seem to assume a key importance in shaping intergroup relations since they often spend more time with the Hungarian helper than with their own parents. After a while, these nannies become like distant relatives and their relationship becomes less formal (e.g., mutual invites and presents, discussing the upbringing of the children).

Another case of cooperative relations concerns Hungarian 'cleaning ladies' who are hired by the better-off Chinese and Vietnamese residents. Although relations of this sort do not necessarily imply that these groups are fully integrated, since they are labour relations principally based on economic considerations as the Hungarian labour force is cheap and easily available, they are meaningful and they can be starting points for the development of wider and deeper interaction, as in the case of Hungarian nannies.

\section{4 “A Marginal Question": The Policymakers' Point of View on Immigration}

"Frankly speaking, immigration is a marginal question in Hungary". This sentence was uttered by a senior researcher at a conference on migrants' chances in the labour market. This viewpoint is very typical among policymakers and experts. The neglect of immigrants by policymakers and the under-representation of Roma, Chinese and Vietnamese in local media within a society that shows highly xenophobic attitudes also widen the gap among these groups and aggravate inter-group relations. Even though the number of migrants is not very significant in Budapest, in the observed interaction sites it is far from negligible. This dichotomy was evident in our interviews. The excuse that 'there are not enough migrants', often sounds like a strategy to dissimulate and justify sheer ignorance of the issue. As the ex-mayor of one of our districts said:

The municipality has never worked on the immigration issue because immigrants do not cause politically relevant problems for the moment. (Kőbánya, ex-mayor in his 50s)

The only municipal-level organization dealing with the equality of chances - a broad and rather heterogeneous basket including the integration of migrants - has one rapporteur in charge of migrants, but they do not have migrant-specific programs 
as they declare that they deal with only one or two migrant-related issues per year. In theory each district of Budapest has its own rapporteur who is also in charge of immigrants at district level but they could hardly be reached during our fieldwork, and, in the few cases when we managed to schedule an interview, they had hardly any information on immigrants living in the districts. ${ }^{13}$ The other sign of political indifference is the inability of politicians working in the districts that host the largest immigrant communities to express their opinions as policymakers; instead they talked about their private xenophobic views. ${ }^{14}$ This example, just one of many, is striking evidence of the low level of tolerance and competence within Hungarian municipalities on questions related to migration. Politicians seem to have no framework within which to form their thoughts and were only able to speak about immigration as a problem that has to be solved by getting rid of all the foreigners. In fact, political parties in Hungary have no explicit policies on the issue, with the exception of Jobbik, the extreme right-wing parliamentary party that swept up $20 \%$ of the votes in the latest elections in 2014 and ranked as the second biggest opposition party. Jobbik stands out in the political arena in that it openly advocates an antiimmigrant policy and it has explicitly introduced the term "Roma criminality" into public speech.

Regarding the civil sphere, the problem is of a different nature. Although some NGOs have the competence to deal with immigrants, have knowledge of their basic needs and deal with them on a daily basis, their resources and therefore also their margins of action are limited. As one of our key informants said when only a few NGOs showed up at a conference organized for municipality members and NGOs to discuss the issue of immigration:

No wonder why they aren't here. Everybody is running after their money. They have no time for meetings like this, they must be working on some tenders at the moment. (Józsefváros, project manager at an NGO dealing with immigrants, 39 years old)

The issue of immigration is neglected not only by the policymakers, but also by the national and local media. In 2008 a study by the Fundamental Rights Agency monitored the two main national daily newspapers ${ }^{15}$ and two tabloids for a 4-week period in order to investigate the representation of minorities and migrant groups.

\footnotetext{
${ }^{13}$ In order to illustrate the attitude of these rapporteurs, it is worth giving a brief account of our attempts to establish contact with them and obtain information on the immigrants living in the districts. We sent out test e-mails to each of the 22 rapporteurs in which we inquired about the number and nationality of immigrant groups living in the districts. Eight answers arrived, five of which contained no information about immigrants.

${ }^{14}$ One of our interviewees, who is a member of the local government envisioned a very dark future by showing his highly oversimplified and stereotypical opinion on the Chinese, saying that they are harmful in taking away jobs from the Hungarians, cheating on taxes, and forcing the Hungarians out of their own country by developing their own institutions. When we asked him why, if this is such a problem, the municipality does not take care of it, we heard another representative of the local government behind us laugh and say 'What could we do about this? We can't do anything, do you think it is possible for us to kick all the foreigners out of the country?' Both of the representatives laughed.

${ }^{15}$ Népszabadság and Magyar Nemzet.
} 
Most coverage dealing with minorities was about the Roma. ${ }^{16}$ News in tabloids was generally concerned with a specific Roma celebrity or with supposed "Roma criminality". In the quality newspapers the most relevant issues concerning the Roma were the activities of Roma politicians, the integration of the Roma, topics about social benefits, crime and violence, and finally cultural news. A recent study of the Hungarian Helsinki Committee (Prischetzky and Szabó 2011) based on 300 articles collected from 70 national homepages examining the negative stereotypes related to migrants in the Hungarian media found that migrants are often reported as criminals and homeless, while their personal life-stories, which would be crucial for understanding them more and for building bridges, hardly appear.

\section{Concluding Remarks}

After the transition to a market economy, Hungary faced an economically challenging era. This transition resulted in a massive social change, leaving many people behind. The Roma and the working class population were severely hit by the downfall of socialism and the consequences of market liberalization. In Józsefváros and Kőbánya most of the inhabitants were from these groups, therefore it came as no surprise that many problems surfaced here sooner and more seriously than in other districts of the capital, amidst greater frustration. The Asian immigrants who settled here in the 1990s mainly saw the chance that the transition period and VISA free entry offered them. Today the coexistence of immigrants and Hungarians is not as conflictual as relations between the Roma and non-Roma. Therefore, we could say that the relations between the host society and immigrants is 'peaceful yet somewhat isolated coexistence', whereby they don't engage in much interaction with the other group.

From a closer perspective, we can conclude that this kind of integration in our neighbourhoods is highly influenced by the urban, economic and social context in which interactions between the host society and migrants take place. We found that the most conflictual relations are the ones in which the immigrants are the most active, namely in commercial sites - the 'Four Tigers Market' and Népszínház Street - due to the Hungarian traders' discontent with what they consider as unfair competition, and the conflicts related to employment issues. The relationship of migrants and Hungarians in residential sites is more peaceful since open conflict seldom erupts and at worst only small problems occur, mainly originating from the cohabitation of people with different cultural backgrounds (i.e., controversies about smelly food or a different lifestyle). On the other hand, the inter-group interactions are less frequent. It is worth underlining that in residential contexts relations developed in the labour market have been of a very different nature than the ones occurring in market sites: these are trust-based relations stemming from care

\footnotetext{
${ }^{16}$ FRA - European Union Agency for Fundamental Rights 2008.
} 
service provided by members of the more deprived layers of the host society to Chinese families.

The perception and judgement of non-EU immigrants in Józsefváros and Kőbánya is highly influenced by the standard of living and social conditions of the host society members. Due to the sharp profit-driven competition on the labour market, ethnic minorities and immigrants working in the area find themselves in a highly complex net of inter-group relations, where competition for scarce resources is the main driving force. To overcome these barriers and balance the economydriven solutions, it would be desirable to have thoughtful and well-planned policies which seek to profit from the diverse communities that live in these districts. As the competencies of the local policymakers and the potential of the NGOs are grossly limited, and issues of immigration and integration are either scarcely or negatively documented in the media, the jury is still out regarding when the situation will change.

Open Access This chapter is distributed under the terms of the Creative Commons AttributionNoncommercial 2.5 License (http://creativecommons.org/licenses/by-nc/2.5/) which permits any noncommercial use, distribution, and reproduction in any medium, provided the original author(s) and source are credited.

The images or other third party material in this chapter are included in the work's Creative Commons license, unless indicated otherwise in the credit line; if such material is not included in the work's Creative Commons license and the respective action is not permitted by statutory regulation, users will need to obtain permission from the license holder to duplicate, adapt or reproduce the material.

\section{Bibliography}

Bell, D. (2000). Guanxi, a nesting of groups. Current Anthropology, 41(1), 133-138.

Benedek, Á. (2007). Gentrification in Józsefváros. Budapest: CEU, Budapest College.

Chu, G. C., \& Ju, Y. (1993). The great wall in ruins. Communication and cultural change in China. Albany: State University of New York Press.

Dupcsik, C. (2009). A magyarországi cigányság története. Történelem a cigánykutatások tükrében, 1890-2008. Budapest: Osiris Kiadó.

FRA - European Union Agency for Fundamental Rights. (2008). Minorities in selected newspapers of six EU Member States: A pilot project. Working paper.

Gödri, I. (2010). Migráció a kapcsolatok hálójában. A kapcsolati tóke és a kapcsolathálók jelenléte és szerepe az ezredvégi magyarországi bevándorlásban. KSH Népességtudományi Kutatóintézet Kutatási Jelentések 89, 2010/2, Budapest.

Gu, Y. U. (1990). Politeness phenomena in modern Chinese. Journal of Pragmatics, 14, 237-257.

György, E. (2012). A Nyolcker a rendszerváltás után - egy városnegyed identitásának meghatározása. $\mathrm{PhD}$ thesis, Eötvös Loránd Tudományegyetem, Budapest.

Józan, P. (2006). Néhány megfigyelés Budapest demográfiai történetéből. Területi Statisztika 9/4. 342-354.

Kasza, S. (Ed). (2005). A láthatatlan történelem látható emlékei. In Az Európai Unió fơvárosaiBudapest - Kóbánya X. kerület (pp. 17-33). Budapest: CEBA Kiadó. 
Kőszeghy, L. (2010). Külföldiek Budapesten. In Változó migráció - változó környezet, Budapest (pp. 221-243). Budapest: MTA Etnikai-nemzeti Kisebbségkutató Intézet.

Melegh, A. (2011). Globalizáció és migráció Magyarországon. Educatio, 2011(2), 206-219.

Nyíri, P. (1996). Magyarország helye a kínaiak világkereskedelmi hálózatában. In Táborlakók, diaszpórák, politikák (pp. 130-138). Budapest: MTA Politikai Tudományok Intézete.

Nyíri, P. (2001). Expatriating is patriotic? The discourse on "new migrants" in the people's Republic of China and identity construction among recent migrants from the PRC. Journal of Ethnic and Migration Studies, 27(4), 635-653.

Nyíri, P. (2010). Kínai migránsok Magyarországon: mai tudásunk és aktuális kérdések. In Változó migráció-változó környezet (pp. 147-171). Budapest: MTA Etnikai-nemzeti Kisebbségkutató Intézet.

Pap, A., \& Simonovits, B. (2006). Ahogy a lakosság, és ahogy a rendôr látja. Az igazoltatási gyakorlat tapasztalatai. Fundamentum, 2006(2), 125-139.

Prischetzky, R., \& Szabó, E. (2011). Migránsok a magyar médiában avagy a bevándorlás és a külföldiek 2011-ben a sajtó szemével. Research paper, Budapest. URL: http://helsinki.hu/wpcontent/uploads/Migransok_a_magyar_mediaban_HelsinkiBiz_2011.pdf

Rév Józsefvárosi Rehabilitációs és Városfejlesztési Z̄rt. (2012). Integrated Social Rehabilitation Study of the Municipality of Józsefváros.

Sik, E. (2010). Az informális piachely a világban. In Piachely, kgst-piac, emberpiac (pp. 39-92). Budapest: TáTK.

Simonovits, B. (2007). Diszkrimináció a plázában. Szociológiai Szemle, 2007(3-4), 135-148.

Simonovits, B., \& Szalai, B. (2012). A személyes ismerős léte és a társadalmi távolság kapcsolata. In Sik, E. \& Simonovits, B. (Eds.), Abena, Sára, Chen és Ali esélyei Magyarországon. Budapest: TÁRKI. pdf document URL: www.tarki.hu/hu/research/migrans/tarki_eia_tanulmanyok_2011.pdf

Simonovits, B., \& Szalai, B. (2013). Idegenellenesség és diszkrimináció a mai Magyarországon. Magyar Tudomány, 2013(3), 251-262.

Solt, O. (1975). Cigányok és cigány gyerekek az iskolában. Beszélő 1992. Új Folyam, (2), $187-210$.

Szalai, Gy. (1970). Lakásviszonyok - szükséglakások. nyomortelepek és gazdasági átalakulás a két világháború között. In Kóbánya története (pp. 113-120; 190-210). Budapest: X. kerület. Tanács.

Szelényi, I., \& Konrád, Gy. (1978). Az értelmiség útja az osztályhatalomhoz (The intellectuals on the road to class power). Bern: Európai Magyar Protestáns Szabadegyetem.

Tilly, C. (2007 [1993]). Áthelyeződött hálózatok. In A migráció szociológiája (pp. 89-104). Budapest: ELTE TáTK.

\section{Online Sources}

Anon. (2014). Így ürítették ki a józsefvárosi piacot. Index, 16 June. URL: http://index.hu/belfold/2014/06/16/jozsefvarosi_piac/. Accessed 30 Aug.

Fischl, Á., \& Valkó, D. (2011). OTP residential property value map. URL: https://www.otpbank. hu/OTP_JZB/file/Ertekterkep.pdf. Accessed 10 June.

KSH (Hungarian Central Statistical Office). (2011). Census 2011 - Demographic data. Retrieved from http://www.ksh.hu/nepszamlalas/tablak_demografia

ORFK. (2008). Registered perpetrators per 100,000 inhabitants in year 2008. National police data from ORFK database. URL: http://archive.today/FZyWj\#selection-16231.0-16235.0. Accessed 30 Oct.

Salát, G. (2013). Bezár a bazár? Válasz.hu, 2 Jul. URL: http://valasz.hu/itthon/bezar-a-bazar-65728. Accessed 10 Sept. 